\title{
We, Polish Jews (My, Żydzi polscy)
}

\author{
Author: Julian Tuwim
}

First Published: 1944 Gwiazda Polarna (Toledo, USA)

Translations: Czech (My, polští Židé, 1944); Hebrew (Anu Jehudej Polin, 1944); Italian (Noi Ebrei Polacchi, 1946); Russian (My, polskije Evreji, 1945); Yiddish (Mir, pojlisze Jiden, 1984); English (We, Polish Jews, 1993).

About the Author: Tuwim (1894-1953) was a poet and translator from French and Russian, and, as author of Locomotive (Lokomotywa, 1938), the best known Polish children's poet. He was born in Lodz in an assimilated family of Polish Jews. He made his debut as a translator in 1911, and as a poet in 1913. In the interwar period (1918-1939) he was the most famous among the poets of his generation, considered as a great artist of the Polish language. At the same time he was a victim of ruthless antisemitic attacks. Co-founder of the magazine Pro Arte et Studio (1916), the literary cafe Pod Picadorem (The Picador Café, 1918) and the poetic group Skamander, Tuwim was also a regular columnist for literary magazines, including Wiadomości Literackie. In September 1939, he escaped from Poland to Brazil and later to the United States. He coworked actively with left-wing émigré circles; returned to Poland in 1946 and settled in Warsaw, coveted by the Communist authorities. He was the chairman of the Society of Friends of the Hebrew University in Jerusalem and the Polish-Israeli Friendship Committee.

Further Important Publications: Czyhanie na Boga (1918, Lurking for God; poems); Sokrates tańczący (1920, Socrates Dancing; poems); Słowa we krwi (1926, Words in Blood; poems); A to pan zna? (1928, Do you Know This Joke?; Jewish jokes); Biblia cygańska (1933, Gipsy Bible; poems); Treść gorejąca (1936, Burning Content; poems); Bal w Operze (created 1936, published 1946, A Ball at the Opera; poem); Kwiaty polskie (created 1940-44, published 1949, Polish Flowers; poem); Pomnik i mogita (1948, Monument and Grave; essay), Nieznany rękopis Juliana Tuwima o antysemityzmie w Polsce. Od stosów do krematoriów - Fun szajterhojnfs biz krematorjes (1974, An Unknown Manuscript of Julian Tuwim about antisemitism. From the Stokes to the Crematories; essay).

\section{Content and Interpretation}

We, Polish Jews is a manifesto (variously known as a message, lamentation, Kaddish, letter, essay, and even a poem) regarding the complicated Polish-Jewish identity. Tuwim wrote it in New York as a reaction to the news of the Warsaw Ghetto Uprising (April-May 1943), and later published it in the London magazine New Poland (August 1944) with a dedication to his "mother in Poland or to her beloved shadow" - the poet

Ә Open Access. () 2021 Katarzyna Kuczyńska-Koschany, published by De Gruyter. (cc) BY-NC-ND This work is licensed under a Creative Commons Attribution-NonCommercial-NoDerivatives 4.0 License. https://doi.org/10.1515/9783110671056-108 
did not yet know that his mother had been murdered by the Germans two years earlier in the Otwock Ghetto. The text is composed in five parts, and in a rhythmic and expressive prose style. In the first part, the poet answers the question: "Where are WE from?" - "I am asked by Jews, whom I have always explained that I am Polish, and now I will be asked by Poles, because for the vast majority of them I am and I will be a Jew" (Tuwim, 1944, p. 491). In the second part, he explains that his Polishness derives from the simplest needs of existence: "To be a Pole - it is neither an honour, nor a boon, nor a privilege. The same is with breathing. I have not met a man who is proud to breathe." Moreover, he argues, "my hatred for Polish fascists is stronger than my hatred for fascists of other nationalities" (p. 491). In the third part, he considers the notion of blood according to two definitions. It is merely "flesh juice", he writes - and whoever considers it beyond this physiological reality is a racist. His second definition has a symbolic dimension: Hitler sheds it "to prove the triumph of his own spirit over my sauce". The poet beseeches the Jews of the world for the title of Polish Jew: "This RANK - the rank of the Jew doloris causa - may it be granted to the Polish poet by the nation that brought him forth. Not for any merits, because I do not have them" (p. 492). In what is the most moving sequence of the fourth part, the poet acknowledges the merit of Polish Jews dying in the Holocaust, as a repository of future symbols: "On the armbands you wore in the ghetto the Star of David was painted. I believe in a future Poland in which this very star, the one from the armbands, will become one of the highest decorations given to the bravest Polish soldiers and officers" (p. 492). The fifth part enumerates the various Jewish martyrs of the Holocaust that make up the "we", with many allusions to Jewish history and culture (pp. 493-494).

\section{Main Topics and Problems}

Tuwim's manifesto, which begins with the personal pronoun "we", deals with numerous European cultural topics - the last of the Mohicans, torture chambers, the figure of Niobe (evoking Greek mythology) -, as well as Judaic and Christian topics, including the martyrdom of bloodshed, the topos of the heroic death, the figure of Job, the lamentation of Jeremia, the figure of Rachel, crying by the rivers of Babylon, and finally - through allusion to the Kaddish - the song El mole rachmim, the act of baptism in Jordan, the ghetto cross and Star of David decoration (he considers these stigmas as distinctions). There are also various specifically Polish references: the figure of Ursula, and the dead child mourned by renaissance poet Jan Kochanowski in his Laments. On the symbolic level, the poet evokes the distinction of doctor honoris causa in his formulation of the Jew doloris causa.

The reception of the text We, Polish Jews was immediate. Two months after its publication, a Hebrew translation appeared in Palestine. The text also circulated around the world and was published in many magazines. Jewish reception of the manifesto, however, was divided. Apolinary Hartglas and Abraham Gołomb (creator of the concept of "integral Jewishness") took exception with Tuwim, asking where he was during the prewar pogroms, and whether the blood of the Jews shed then was less 
red than that shed during the Holocaust. They also consider his idea of the "Jew doloris causa" to be unauthorised and overdue. On the other hand, Ilya Erenburg writes: "Tuwim's words are written with blood." Elsewhere the reception of Tuwim's manifesto was contextualised specifically in issues of identity, and self-identification by Polish Jews (Halina Birenbaum, Stanisław Wygodzki). After years, the manifesto still arouses strong emotions. In a discussion about Tuwim published in the journal Midrasz (2013), Bella Szwarcman-Czarnota declares her belief that "postwar [Tuwim's] choices seem to be just for show; in general, Tuwim seems to be 'too much': he screams too loudly, demonstrates too strongly". Tuwim's monographer Piotr Matywiecki answers polemically that the confessional tone of We, Polish Jews finds a kind of continuation in his essay The Monument and the Grave, inspired by Lévinas and written for the unveiling of the monument of the Ghetto Heroes (sculpted by Natan Rapoport). It is in this essay that Tuwim speaks of "a man without a homeland" (neither a Jew, a Pole nor a European), and about "human nudity" towards the event of the Holocaust. Michał Głowiński, in turn, considers We, Polish Jews to be "an embarrassing" text which begins "almost as a column" ("I am Polish, because I like it so much") before shifting to the tone of the Kaddish - a lamentation, and in this case, a deeply incoherent one. Matywiecki considers this inconsistency to be "dramatic", "extremely moving”, and "almost hysterical" on the existential level.

\section{Cited Works}

Matywiecki P. (2007). Twarz Tuwima. Warszawa: Wydawnictwo W. A. B., pp. 266-270, 324-325. Molisak, A., Szwarcman-Czarnota, B., Głowiński, M., Matywiecki, P. (2013). Julian Tuwim. Midrasz, 5(175), pp. 12-20. Szwarcman-Czarnota B. (2013). Żydowski dwugłos o Tuwimie. Midrasz, 5 (175), pp. 26-27. Tuwim, J. (1944). My, Żydzi polscy. Nowa Polska, (8), pp. 491-494.

\section{Further References}

Adamczyk-Garbowska M. (2013). Trudne tematy w twórczości Juliana Tuwima. Midrasz, 5 (175), pp. 36-39. Adamczyk-Garbowska M., ed., (2015). Żydowskie konteksty twórczości Juliana Tuwima. Lublin: Wydawnictwo Uniwersytetu im. Marii CurieSkłodowskiej. Francesco, Simone Di (2007). Apocalypse in Poland: Julian Tuwim's Poetry (1894-1953). East European Quarterly, 41(2), pp. 205-221. Goldberg I. (2013). Czy naprawdę przyszedł za późno? W sprawie J. Tuwima i A. Gołomba. Midrasz, 5 (175), pp. 31-35. Gołomb A. (2013). Za późno. List zwyczajnego żydowskiego Żyda do polskiego Żyda. Midrasz, 5(175), pp. 28-30. Löw, R. (1996). „My, Żydzi polscy...“ w hebrajskiej opinii literackiej. In: R. Löw, Hebrajska obecność Juliana Tuwima: szkice literackie. Łódź: Oficyna Bibliofilów, pp. 17-22. Naimska M., Żebrowski R. (2003). Tuwim Julian. In: Z. Borzymińska, R. Żebrowski, eds., Polski słownik judaistyczny. Dzieje. Kultura, Religia. Ludzie, volume. 2. Warsawa: Prószyński i S-ka, pp. 748-749. Paziński, P., Datner, H. (2015). Jankiel, chasydzi i Tuwim. Midrasz, 1(183), pp. 4-10. Kunert, A. K., ed. (2001). Polacy - Żydzi / Polen - Juden / Poles - Jews 1939 - 1945. Wybór źródet. 
Warszawa: Rytm Press. Sobelman, M. (2014). Syjoniści kontra „Żydzi polscy“. Palestyńskie echa memoriału Tuwima. Acta Universitatis Lodziensis. Folia Litteraria Polonica. 4(26), pp. 101-111. Urbanek, M. (2013). My, Żydzi polscy. In: J. Tuwim, Wylękniony bluźnierca. Warszawa: Wydawnictwo Iskry, pp. 203-205. Wygodzki, S. (1963), Będzin. In: W. Jedlicka, M. Toporowski, eds., Wspomnienia o Julianie Tuwimie. Warsaw: Czytelnik, pp. 170-171. Zalewska, G. (2000). Tuwim Julian. In: A. Cała, H. Węgrzynek, G. Zalewska, eds., Historia i kultura Żydów polskich. Stownik. Warszawa: Wydawnictwa Szkolne i Pedagogiczne, pp. 356-357.

KKK 